\title{
携帯電話を利用した会話が運転行動に及ぼす影響について \\ Effects of Talking through Cellular Telephone on Driving Behavior
}

\author{
德永 ロベルト アブラ八ム* 萩原 亨** 加賀屋 誠一** 小野寺 雄輝** \\ Authors: R. Tokunaga*, T. Hagiwara**, S. Kagaya** and Y. Onodera**
}

\section{1. はじめに}

著者らは、平成 8 年度に携帯電話の設置位置の違いに よる比較実験 ${ }^{1)} 、$ 北海道開発局開発土木研究所のドラ イビングシミュレータにおいて実施し、ドライバーへの影響 を検討した。結果として、ハンズフリーシステムを用いた携 帯電話使用の方が助手席に置いた状態よりも操作性がよ く、ドライバーへの影響が少ない結論に至った。

平成 9 年度には、著者らは道央自動車道においてハン ズフリーシステムを用いた携帯電話による会話が運転に与

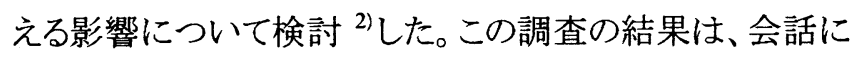
よる影響はあるが、場面によっては対応可能であることを 示していた。また、自動車安全運転センターも同年度に携 帯電話使用が運転挙動に及ぼす影響について模擬市街 路において検討した結果 ${ }^{3)}$ を報告した。この研究において、 片手運転による携帯電話使用の方がハンズフリーシステ ムを使用した場合よりも反応時間、視線移動及び進路保 持性への影響が大きくなると報告している。れに伴って、 政府は平成 11 年 11 月 1 日から道路交通法の改正によっ て一部の条件を除いて自動車運転中の携帯電話及びそ

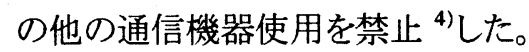

ハンズフリーシステムを用いた携帯電話を採用すること により、自動車運転への影響が軽減されるとする研究が多 いが、それによって従来から指摘されている携帯電話使用 の危険性が解決されたと言えるだろうか。また、携帯電話 を使った会話の内容が異なることによってドライバーにど の程度の影響を及ぼすかは不明と言える。

よって、本研究では会話内容の違いによるドライバーへ の影響を厳密に検討するため、高速道路上の走行におけ る会話についてメンタルワークロード ${ }^{5)}$ という観点から試み ることとした。このメンタルワークロードへの影響度を推定 するために、一つは反応時間の遅延、もう一つは主観的 評価といら2つの測度を用いることとした。具体的には、道 央自動車道において追従運転時にハンズフリーシステム を用いた携帯電話を通して簡単な会話と難しい会話をす るという実験を若年ドライバー(以下、若年者)及び高路ド

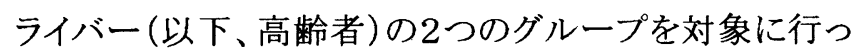
た。

Key Words: 交通情報、交通安全、ITS

*学生員 $* *$ 正会員、北海道大学 大学院 工学研究科

（T060-8628 札幌市北区北 13 条西 8丁目、 Tel: 011-706-6214、

Fax: 011-726-2296、E-mail: roberto@eng.hokudai.ac.jp)
表 1 被験者構成

\begin{tabular}{|c|c|c|c|}
\hline 若年者 & 年䤅 (f) & 運転歴 (年) & 年間走行距離 $(\mathrm{Km})$ \\
\hline 平均值 & 23.9 & 5.1 & 12,200 \\
\hline 標準偏差 & 2.8 & 3.1 & 6.630 \\
\hline 平均値 $+S D$ & 26.7 & 8.2 & 18,830 \\
\hline 平均值 $-\mathrm{SD}$ & 21.2 & 2.0 & 5,570 \\
\hline サンフル数 & 19 & 19 & 19 \\
\hline
\end{tabular}

\begin{tabular}{|c|c|c|c|}
\hline 高齵者 & 年齡(才) & 運転歴 (年) & 年間走行距離 (Km) \\
\hline 平均值 & 62.8 & 39.2 & 12,750 \\
\hline 㯲準偏差 & 2.3 & 3.9 & 5,950 \\
\hline 平均値 $+S D$ & 65.0 & 43.0 & 18,700 \\
\hline 平均值 - SD & 60.5 & 35.3 & 6,800 \\
\hline サンブル数 & 12 & 12 & 12 \\
\hline
\end{tabular}

\section{2. 実験方法}

\section{（1）被験者構成}

本実験では、若年者及び高齢者という 2 つのグループ を実験に用いることにより、各グループのメンタルワークロ 一ド特性が得られると考えた。実験には、若年者 19 名 (男 性 16 名·女性 3 名)及び高齢者 12 名 (全員男性) 計 31 名が参加した。ただし、高齢者の場合は高速道路上にお ける実車走行であったため、実験に参加可能なドライバー のみを採用したことを示す必要がある。また、若年者・高齢 者全員が運転中の携帯電話使用経験又は通信機器使用 経験を有する者だった。被験者の調査区間における過去 の走行経験は大半が年に $1 \sim 5$ 回だった。表 1 に、本実験 に参加した被験者の年齢構成、運転歷及び年間走行距 離を示す。

\section{（2）調查区間}

実験走行は、平成 11 年 5 月 31 日から 6 月 12 日にか けて直線が多く勾配の少ない道央自動車道の江別西イン ターから岩見沢インターの往復区間 $(50.6 \mathrm{~km})$ で行った。 実験は晴れのみの時及び午前 10 時〜午後 3 時の間に実 施した。実験は上り及び下り線を含めて約 1000 台/h という 交通流状況において実施した。

\section{（3）実験車両}

実車実験には、以下の車両 2 台を用いた。 先行車両: 隊列の先頭を走行した。実験者は、これに乗車 し被験者にタスクの指示を行った。

追従車両：この車両には、被験者のみが乗車した。車 内のダッシュボード（ハンドルの左付近）には、ハン ズフリーシステムを用いた携帯電話が設置された。ま た、デジタルビデオカメラ及び計測機器を後部座席に 
設置し、運転挙動の計測記録を行った。

追従車両に設置された携帯電話の電源は常時つけて おき、受信時け受信ボタンのみ及び会話を解除する場合 はホールドボタンのみで操作できる状態にし、携帯電話の 操作を最も簡単にできるような環境を設定した。電話使用 の指示は、先行車両に乗車している実験者が行った。図 1 に、追従車両のハンドル付近に設置した携帯電話及び被 験者による操作状況を示す。

\section{（4）自動車運転中の会話内容}

ドライバーのメンタルワークロードの検討には、二重課題 法を採用した。主課題には、運転タスクを用いた。二次課 題には、携帯電話を通した会話を用いた。携帯電話を通 して行った会話の内容は、以下の 2 種類である。

（a）普通会話:追従運転中に携帯電話を通して車間距離 の調整、車両及び道路環境に慣れたか、電話はよく 通じているか、どのインターで降りるかというような具体 的で簡単な会話が実験者と被験者の間で行われた (会話時間:約 2 分)。

(b) 暗算課題: 本研究では、すべての被験者に同程度の 記憶及び考察作業かつ普通会話と明らかに異なって 困難度の高い課題を与えるため暗算課題を用いた。 具体的には、被験者に足し算及び引き算の組合せ問 題を提示し計算させた(例: 「7+1+1-1+1 は...? ?)。更 に、被験者が 2 つ目の問題を答えた後、実験者は被 験者に一番目と二番目の回答を思い出すように伝え、 2 つの回答を続けて答えさせた。回答後、問題を 3 つ に増やし同じ作業をもう一度繰り返した(会話時間:約 2 分)。

\section{(5) 反応時間の測定}

本実験では、先行車両がルーフのパトロールランプを点 灯させた時点から、追従車両に乗車している被験者が八 ンドルに設置した押しボタンを押すまでの経過時間を反応 時間として定義した。

被験者の反応時間測定は、追従車両に設置した計測機 器及びデジタルビデオカメラによって行われた。計測機器 は、時刻、移動距離及び車間距離を収録した。センサー によって得られたデータは、1/20 秒のサンプリングで、パソ コンにより記録収集した。また、後部座席に設置されたデ ジタルビデオカメラは先行車両のパトロールランプ、被験 者の様子、反応時間及び移動距離を示すカウンター外部 ディスプレイを撮影した。パソコン及びデジタルビデオカメ ラの同期は、ビデオ映像から得たカウンター值とパソコン から出力されたカウンター值の比較によって一致させた。 図 2 に、先行車両及び追従車両に設置された計測機器及 び走行状況を示す。

(6) 主観的メンタルワークロードの測定

メンタルワ・多ロ・゙は、精神的作業による生体負荷

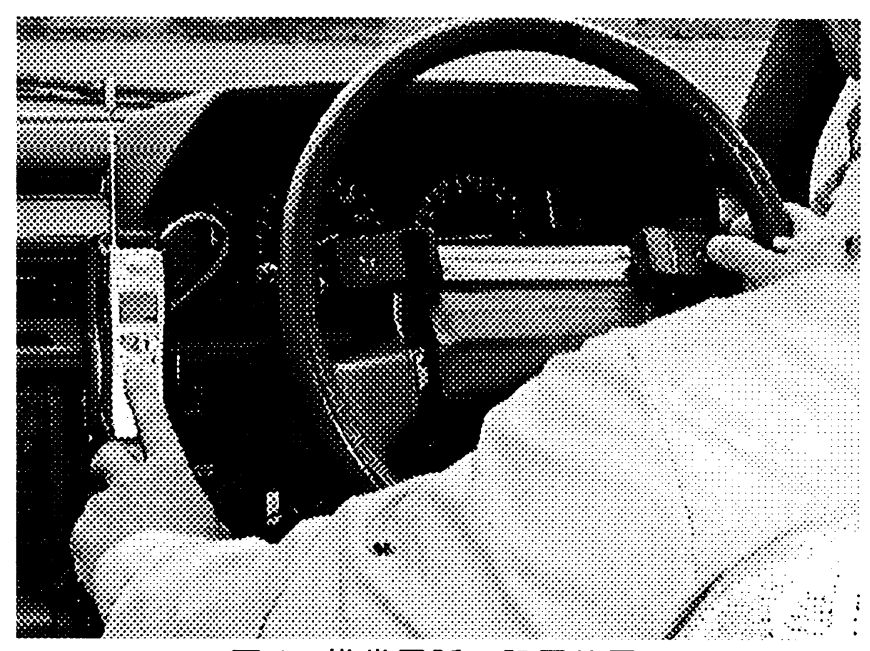

図 1 携帯電話の設置位置

表 2 TLX6 項目の説明内容

\begin{tabular}{|c|c|c|}
\hline \multicolumn{3}{|c|}{ 本研究に用いたTLXの6項目及び説明 } \\
\hline 項目名 & 端点 & \begin{tabular}{|c|} 
説明 \\
\end{tabular} \\
\hline 啨神的要求 & 小・大 & $\begin{array}{l}\text { 課題を実行中に、道路を見る、 } \\
\text { 指示·筧問を聞く、会話内容を } \\
\text { 記憶する、考える等どれくらい } \\
\text { の知覚的活動が必要だったと } \\
\text { 感じました。 }\end{array}$ \\
\hline 身体的要求 & 小・大 & $\begin{array}{l}\text { ハンドルのボタンを押す_ハン } \\
\text { ドルを回す、動き回る、制御す } \\
\text { る等どれくらいの身体的活動 } \\
\text { が必要だたた感じましたた。 }\end{array}$ \\
\hline 仕しさ & 小・大 & $\begin{array}{l}\text { 課題の頻度または速度から感 } \\
\text { した時間的圧力はどの程度 } \\
\text { だったと思いますか。 }\end{array}$ \\
\hline 努力 & 少ない·多い & $\begin{array}{l}\text { 課題の維持·達成にどの程度 } \\
\text { かんばったと思っていますか。 }\end{array}$ \\
\hline 達成度 & 良い·悪い & $\begin{array}{l}\text { 課題目標についてどの程度成 } \\
\text { 功したと思っていますか。 }\end{array}$ \\
\hline 不満度 & 低い·高い & $\begin{array}{l}\text { 作業中に、いらいら、不安、落 } \\
\text { 胆、ストレス、悩み等をどの程 } \\
\text { 度感じましたか(作業がうまくで } \\
\text { まかったという思い)。 }\end{array}$ \\
\hline
\end{tabular}

（Mental Stress）を示す場合のほか、精神的作業による 生体負担 (Mental Strain)をも含めている。生体負荷は、外 部から人間に対して及ぼし、かつ精神的に作用する影響 の全体である。また、生体負担は生体負荷によって個人の 内部に直ちに起こる影響である。

本研究では、ドライバーの主観的メンタルワークロード測 定のために欧米諸国で最も一般的に使用されている NASA Task Load Index ${ }^{6)}$ (以下、TLX)を指標として用いた。 TLX は、飛行士の主観的メンタルワークロード評価を目的 として作成された多次元の格付手法である。TLX の主観 的メンタルワークロードは、精神的要求、身体的要求、忙 しさ、努力、達成度及び不満度の6 項目から構成されてい る。本研究では、この手法を一般ドライバーにもわかりやす 〈するため、三宅 ${ }^{7)}$ 及び芳賀 ${ }^{8)}$ が紹介した 6 項目の説明を 更に改善し、簡易化及び具体化した。表 1 に、本実験で 採用した TLX6 項目の説明内容を示す。

被験者は、質問用紙において与えられた特定のタスクに 対して尺度の「小さい/大きい小「低い/高い」又は「良い/悪 いの两極を持の項日の線分上に、評定尺度によって゚ 


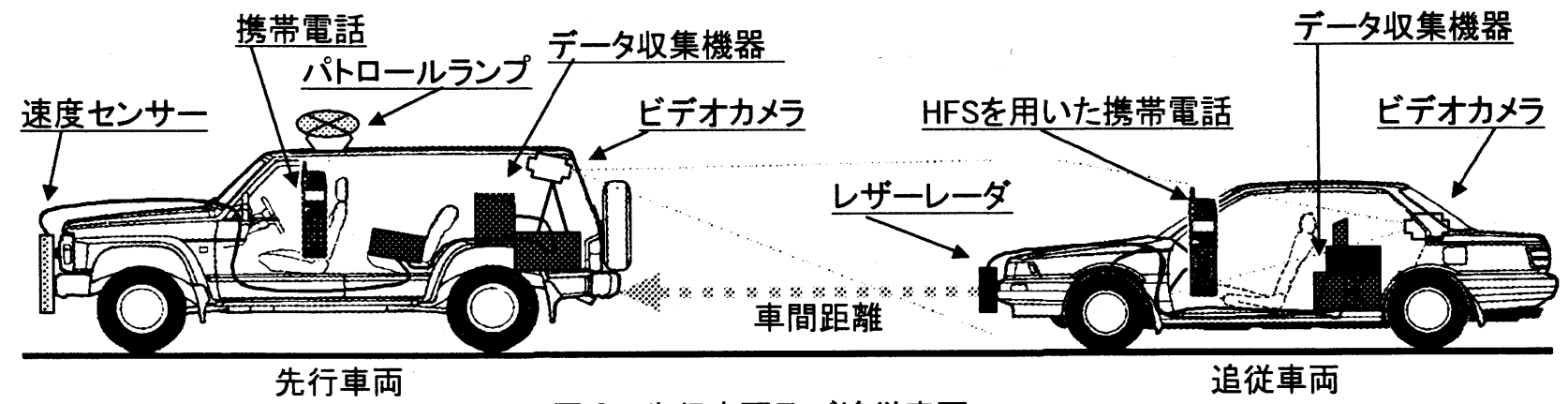

図 2 先行車両及び追従車両

印をつける。被験者が位置付した○印は、分析時におい て $0 \sim 10$ の数值に変換し、被験者の主観的な評価を数值 化する。TLX は、6 項目の評価值から総合值(平均值)を 算出し、タスクを遂行したドライバーの主観的メンタルワー クロードを提供するといった特徵を持っている。

\section{（7）実験内容}

独立変数として、運転のみ (追従運転)、運転中に電話 を受ける(電話操作)、運転中に実験者と事務的会話をす る(普通会話) 及び運転中に実験者の暗算問題に答える (暗算課題)という4つのタスクと若年者及び高齡者の $2 つ$ のグループを考えた。携帯電話を用いた会話内容の違い による影響を評価する従属変数として、被験者の反応時 間及び主観的メンタルワークロードの変化を考えた。

被験者は、高速道路上で先行車両と一定の車間距離 (約 $50 \mathrm{~m}$ ) を維持しながら走行 (約 $90 \mathrm{~km} / \mathrm{h}$ ) するといら課題 で、追従運転、電話操作、普通会話及び暗算課題の 4 つ のタスクを行った。各被験者の実験走行は、1 往復のみ (練習走行なし)とした。携帯電話を用いた普通会話及び 暗算課題は、往路及び復路のどちらかに一回ずつランダ ムに振り分けられた。

電話操作 (往復)の時を除いて、追従運転 (往復)、普 通会話及び暗算課題を実行中に先行車両のパトロールラ ンプの点灯(約 5 秒)がそれぞれに一回ずつ設けられた。

\section{(8) 実験手順}

被験者は、追従車両に乗車し、安全確認を行った。次に、 被験者は本実験の目的、追従走行、車間距離、及び注意 事項について説明を受けた。連絡用の携帯電話の位置と ハンズフリーシステムの機能・操作方法について説明を受 け、電話操作及び会話の練習を行った。江別西インター から中間地点の岩見沢インターまで走行した被験者は、 実験者の説明・指示に従って TLX 用紙に記入した。休憩 を終えた後、被験者は前半と同じ要領で岩見沢インター から江別西インターまでの区間を走行した。江別西インタ 一に到着し、実験を終えた被験者は、再び TLX用紙及び アンケートに記入した。

\section{3. 実験結果}

表 3 反応時間

\begin{tabular}{|c|c|c|c|c|}
\hline \multirow{3}{*}{ 若 年 者 } & \multicolumn{4}{|c|}{ 反俯 時間（秒） } \\
\hline & 往 路 & 复路 & & \\
\hline & 追従運転 & 追従運転 & 普通会話 & 暗算 課 題 \\
\hline 被跧者 1 & 0.63 & 0.60 & 0.70 & 0.83 \\
\hline 被験者 2 & 0.50 & 0.50 & 0.70 & 1.77 \\
\hline 被験者 3 & 0.59 & 0.49 & 0.67 & 0.83 \\
\hline 被験者 4 & 0.43 & 0.77 & 0.57 & 0.87 \\
\hline 被騃者 5 & 0.54 & 1.20 & 1.33 & 0.87 \\
\hline 被䘒者 6 & 0.65 & 0.47 & 0.73 & 0.83 \\
\hline 被験者 7 & 0.62 & 0.42 & 0.57 & 0.73 \\
\hline 被酸者 8 & 0.50 & 0.47 & 1.07 & 1.03 \\
\hline 被医著 9 & 0.55 & 0.47 & 0.63 & 0.67 \\
\hline 被験者 10 & 0.49 & 0.47 & 0.77 & 0.53 \\
\hline 被騃者 11 & 1.12 & 0.99 & 0.80 & 1.67 \\
\hline 被験者 12 & 0.65 & 0.45 & 0.50 & 0.67 \\
\hline 被験者 13 & 0.82 & 0.67 & 0.80 & 1.20 \\
\hline 被酸者 14 & 0.50 & 0.63 & 0.77 & 1.27 \\
\hline 被騃者 15 & 0.52 & 0.53 & 0.77 & 0.67 \\
\hline 被験者 16 & 0.50 & 0.43 & 0.80 & 1.10 \\
\hline 被硂者 17 & 1.05 & 1.09 & 2.30 & 0.93 \\
\hline 被験者 18 & 0.90 & 0.87 & 0.93 & 1.37 \\
\hline 被験者 19 & 0.52 & 1.05 & 0.67 & 0.63 \\
\hline 平均値 & 0.63 & 0.66 & 0.85 & 0.97 \\
\hline 標準膈差 & 0.20 & 0.26 & 0.40 & 0.35 \\
\hline
\end{tabular}

\begin{tabular}{|c|c|c|c|c|}
\hline \multirow[b]{2}{*}{ 高秢者 } & \multicolumn{4}{|c|}{ 反広時間（秒） } \\
\hline & 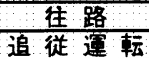 & 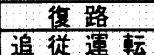 & 暮通会 話 & 暗笧課頉 \\
\hline 被䣯者 1 & 0.84 & 0.74 & 0.43 & 1.03 \\
\hline 被俟者 2 & 0.70 & 0.70 & 0.83 & 1.07 \\
\hline 被蹒者 3 & 0.83 & 0.57 & 1.00 & 1.00 \\
\hline 被験者 4 & 1.05 & 0.74 & 0.70 & 1.07 \\
\hline 被䣯者 5 & 0.74 & - & 0.97 & - \\
\hline 被験者 6 & 0.55 & 0.49 & 0.80 & 0.90 \\
\hline 被験者 7 & 0.53 & 0.47 & 0.77 & 1.03 \\
\hline 被垁者 8 & 0.53 & 0.52 & 0.67 & 1.03 \\
\hline 被耠者 9 & 1.64 & 0.80 & - & 1.03 \\
\hline 被験著 10 & 0.52 & 0.40 & 1.07 & 0.87 \\
\hline 被铁者 111 & 0.60 & 0.84 & 1.20 & 0.97 \\
\hline 被験者 12 & 0.63 & 0.45 & 0.60 & 0.87 \\
\hline 平均 & 0.76 & 0.61 & 0.82 & 0.99 \\
\hline 䅺準偏 差 & 0.32 & 0.16 & 0.22 & 0.08 \\
\hline
\end{tabular}

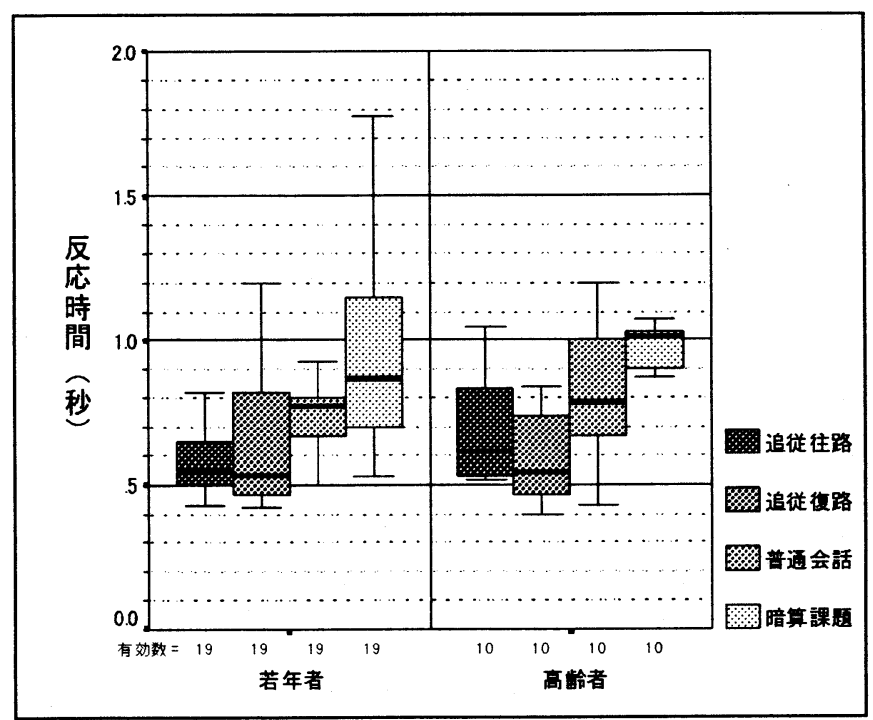

図 3 反応時間 
(1) 反応時間

本実験では、被験者 31 名中 29 名から反応時間を得ること ができた。残り 2 名の反応時間は、計測機器の操作ミスに よる原因から測定が不可能となった。被験者のグループ構 成は、若年者 19 名及び高齢者 10 名となった。反応時間 は、追従運転 (往路)、追従運転(復路)、普通会話及び暗 算課題の 4 つのタスクから測定した。表 3 に、被験者の反 応時間を示す。

追従運転 (往復)における両者の反応時間は、0.61 から 0.76 秒の平均値を示した。一方、普通会話における反応 時間は、若年者が 0.85 秒及び高齢者が 0.82 秒と追従運 転時に比べて両者とも遅延していた。また、暗算課題の反 态時間においても、若年者が 0.97 秒及び高齢者が 0.99 秒と更に長くなっていた。図 3 に示す箱型図は、両者の追 従運転 (往復)、普通会話及び暗算課題における反応時 間の結果をパーセンタイルで示したものである。

\section{(2) 主観的メンタルワークロード}

被験者構成は、若年者 19 名及び高齢者 12 名 (計 31 名)となった。被験者は、追従運転 (往路)、追従運転(復 路)、電話操作 (往路)、電話操作 (復路)、普通会話及び 暗算課題の 6 つのタスクにおいて主観的メンタルワークロ 一ドの評価を行った。表 4 に、被験者の主観的メンタルワ ークロードを示す。

追従運転 (往復)における両者の主観的メンタルワーク ロード得点は、 3.63 から 4.00 の平均値を示した。電話操作 (往復)に対しては、若年者が 5.03 及び 4.74 となり、高齢 者が 4.72 及び 4.15 と各々の追従運転に比べて増加して いた。普通会話における主観的メンタルワークロードは、 若年者が 5.04 及び高齢者が 4.49 となり、後者の場合は電 話操作の結果より低い平均値を示した。一方、暗算課題 に対してては、若年者が 6.90 及び高齢者が 5.31 となり、それ ぞれのタスク評価の中で最も高い值を示していることがわ かった。

図 4 の箱型図は、若年者·高齢者の追従運転(往復)、 電話操作 (往復)、普通会話及び暗算課題における主観 的メンタルワークロードの結果をパーセンタイルで示したも のである。

\section{(3) 被験者の分類}

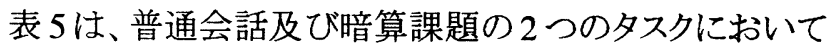
測定した各被験者の反応時間と主観的メンタルワークロー ドを若年者之高齢者に分けて分類を行った結果を示して いる。以下に、分類の内容を示す。
（a）反応時間及び主観的メンタルワークロード得点が増 加した者。
（b） 反応時間が遅延したが、主観的メンタルワークロード 得点が増加しなかった者。
（c）反応時間が遅延せず、主観的メンタルワークロード 得点が増加した者。

表 4 主観的メンタルワークロード

\begin{tabular}{|c|c|c|c|c|c|c|}
\hline \multirow{3}{*}{ 若 年 者 } & \multicolumn{6}{|c|}{ 主哯的メンタルワークロ-ト (得点) } \\
\hline & & & & & & \\
\hline & $\begin{array}{l}\text { 追従 } \\
\text { 運転 }\end{array}$ & $\begin{array}{l}\text { 雷 話 } \\
\text { 壦 }\end{array}$ & $\begin{array}{l}\text { 追 従 } \\
\text { 運 }\end{array}$ & $\begin{array}{l}\text { 電 話 } \\
\text { 杵 }\end{array}$ & 会 & 暗 甚 \\
\hline 被娩者 1 & 2.9 & 4.9 & 3.0 & 5.0 & 5.8 & 7.2 \\
\hline 被唤者 2 & 3.2 & 3.8 & 4.8 & 5.8 & 6.8 & 6.5 \\
\hline 被 龭 者 3 & 1.3 & 3.0 & 1.0 & 1.2 & 2.3 & 7.1 \\
\hline 被験者 4 & 4.7 & 6.7 & 5.5 & 7.3 & 4.5 & 6.3 \\
\hline 被軮者 5 & 5.6 & 6.2 & 5.4 & 5.5 & 5.8 & 8.0 \\
\hline 被 験 者 6 & 5.0 & 5.7 & 2.7 & 3.4 & 5.2 & 5.6 \\
\hline 被験者 7 & 4.5 & 5.8 & 5.4 & 5.8 & 5.4 & 6.9 \\
\hline 被験 者 8 & 1.2 & 2.1 & 2.3 & 3.3 & 6.0 & 8.8 \\
\hline 被 騃 者 9 & 1.5 & 2.6 & 1.6 & 2.3 & 1.6 & 5.4 \\
\hline 被酸者 10 & 4.1 & 7.3 & 2.3 & 5.8 & 4.7 & 7.6 \\
\hline 被験者 11 & 2.9 & 3.9 & 2.6 & 3.2 & 3.7 & 4.4 \\
\hline 被験者 12 & 1.0 & 1.0 & 1.0 & 1.0 & 1.0 & 2.3 \\
\hline 被験者 13 & 5.5 & 6.0 & 6.2 & 6.5 & 7.2 & 8.2 \\
\hline 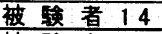 & 3.7 & 4.4 & 2.7 & 3.5 & 3.3 & 7.8 \\
\hline 被験者 15 & 6.3 & 7.8 & 7.0 & 7.5 & 7.8 & 8.8 \\
\hline 被験者 16 & 5.2 & 5.4 & 5.3 & 5.4 & 6.0 & 8.5 \\
\hline 被験者 17 & 5.6 & 6.3 & 5.0 & 5.8 & 5.6 & 6.4 \\
\hline 被験者 18 & 5.3 & 7.8 & 5.3 & 7.8 & 6.0 & 9.2 \\
\hline 被験者 19 & 4.0 & 4.8 & 3.8 & 4.1 & 7.2 & 6.2 \\
\hline 平均值 & 3.86 & 5.03 & 3.83 & 4.74 & 5.04 & 6.90 \\
\hline 㮛準偏差 & 1.68 & 1.93 & 1.84 & 2.01 & 1.90 & 1.69 \\
\hline
\end{tabular}

\begin{tabular}{|c|c|c|c|c|c|c|}
\hline \multirow{3}{*}{ 高秢 者 } & \multicolumn{6}{|c|}{ 主钼的メンタルワークロート（得点） } \\
\hline & & & 行 & & & \\
\hline & 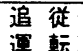 & 電話 & 追徉 & $\begin{array}{l}\text { 電話 } \\
\text { 諻 }\end{array}$ & $\begin{array}{l}\text { 晋通 } \\
\text { 会話 }\end{array}$ & $\begin{array}{l}\text { 橦 基 } \\
\text { 課 題 }\end{array}$ \\
\hline 被験者 1 & 4.7 & $\frac{2 \times}{4.8}$ & 4.7 & $\frac{2.8}{4.8}$ & 4.7 & 4.7 \\
\hline 被唤者 2 & 5.7 & 6.2 & 5.5 & 5.5 & 7.2 & 6.5 \\
\hline 被缶著 3 & 3.3 & 4.2 & 2.8 & 2.8 & 2.8 & 4.0 \\
\hline 被験者 4 & 4.8 & 7.2 & 3.7 & 6.3 & 4.8 & 7.8 \\
\hline 被娩者 5 & 4.8 & 5.0 & 5.3 & 5.8 & 5.3 & 5.3 \\
\hline 被愥者 6 & 6.2 & 6.2 & 4.3 & 4.7 & 6.3 & 8.3 \\
\hline 被输 者 7 & 2.3 & 2.7 & 2.8 & 4.7 & 3.0 & 4.0 \\
\hline 被娩者 8 & 4.5 & 6.0 & 4.3 & 4.5 & 5.2 & 6.8 \\
\hline 被秧者 9 & 2.7 & 2.7 & 2.2 & 2.2 & 2.7 & 3.1 \\
\hline 被涘者 10 & 4.0 & 4.9 & 3.7 & 4.3 & 4.7 & 5.4 \\
\hline 被籍著 11 & 3.1 & 4.8 & 2.5 & 2.0 & 4.3 & 5.1 \\
\hline 被䖝者 12 & 2.0 & 2.2 & 1.7 & 2.2 & 3.0 & 2.7 \\
\hline 平均值 & 4.00 & 4.72 & 3.63 & 4.15 & 4.49 & 5.31 \\
\hline 標準富差 & 1.32 & 1.57 & 1.24 & 1.50 & 1.43 & 179 \\
\hline
\end{tabular}

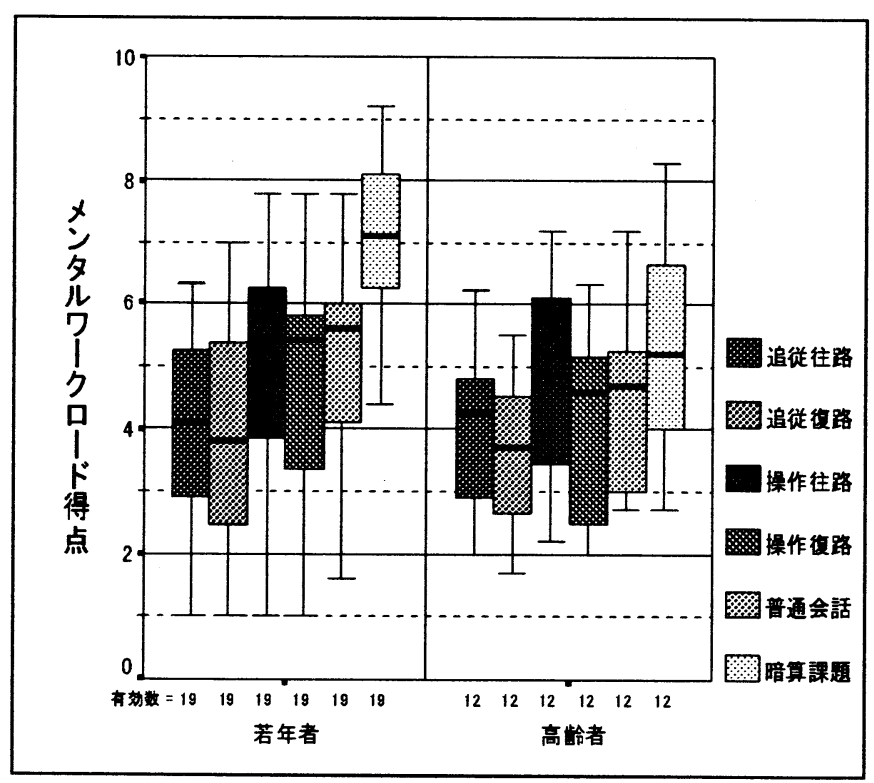

図 4 主観的メンタルワークロード

表 5 反応時間の遅延と主観的メンタルワークロード の増減による被験者の分類

\begin{tabular}{|c|c|c|c|}
\hline \& 14 d & $(x)$ & 葫 年量 & 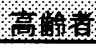 \\
\hline 遅延あり & 增加あり & 12名 & 4名 \\
\hline 遲延あり & 增加なし & 1名 & 3名 \\
\hline 進延なし & 増加あり & 5名 & 3名 \\
\hline 遅延なし & 增加なし & 1名 & - \\
\hline
\end{tabular}


（d） 反応時間及び主観的メンタルワークロード得点が増 加しなかった者。

結果として、若年者の 19 名中 12 名が (a)及び 5 名が (c) の2つのグループに集中した。高齢者の場合は、ほぼ同じ 割合で $(a) 、(b)$ 及び (c)の3つのグループに分かれている のが認められた。

\section{4. 考察}

本研究で得られた結果について考察したい。本実験に 参加した被験者の反応時間は、 $\mathrm{Alm}^{9{ }^{9}}$ らの研究結果に比 べて短くなっていることがわかった。この理由は、勾配が少 ない直線道路での追従運転及びハンズフリーシステムを 用いた携帯電話の使用という単純な課題において、被験 者の視線が先行車両の後方に集中し、視線の移動をほぼ 要せずに前方の状況を把握できたためだと考えられる。ま た、電話タスク時の反応時間において若年者の標準偏差 が運転タスクに比べて大きくなった。これは、二次課題によ る作業負荷が被験者の反応時間に影響したものと考えら れる。しかし、高齢者の反応時閒の標準偏差は普通会話

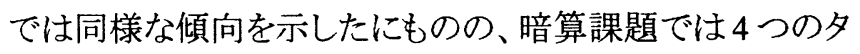
スクの中で最も小さい值を示した。このような結果をもたら した理由については、本研究において特定することができ なかった。

若年者・高齢者 (被験者間因子 2 水準)及び追従運転 (往復)、普通会話、暗算課題時の反応時間 (被験者内因 子 4 水準)の違いについて、 2 元配置 (対応のない因子と 対応のある因子)の分散分析を行った。その結果、若年者 と高齢者の間では交互作用が認められず、両者の電話タ スク時における反応時間の遅延は追従運転に比べて同様 に増加した $(\alpha=.05)$ 。また、Tukey の正確有意差(HSD) 検定による多重比較では、追従運転 (復路) ·普通会話及 び追従運転 (往復)・暗算課題の間で反応時間が有意に 増加した。表 6 にこれらの結果を示す。

同じく、若年者・高齢者 (被験者間因子 2 水準)及び追 従運転 (往復) ·電話操作 (往復) - 普通会話・暗算課題時 の主観的メンタルワークロード(被験者内因子 6 水準)の違 いについて 2 元配置 (対応のない因子と対応のある因子) の分散分析を行った。その結果、若年者之高齢者の間で 交互作用が認められ $(\mathrm{F}(5,145)=3.254, \mathrm{p}<.05)$ グループ間 の違いを示した。しかし、両者の電話タスク時における主 観的メンタルワークロードの得点は追従運転に比べて有 意に増加した $(\alpha=.05)$ 。Tukey の HSD 検定による多重比 較では、特に暗算課題と他のタスクとの比較において得点 が有意に増加した $(\alpha=.05)$ 。表 7 にこれらの結果を示す。

更に、会話内容の異なりによる反応時間及び主観的メ ンタルワークロードの関係について調べた。若年者の反応 時間は、0.12 秒(1.14 倍)の遅延及び主観的メンタルワー クロードでも 1.86 点 (1.37倍)の増加を示し、両測度の比率 が 0.82 となった。同様に、高齢者の反応時間も 0.17 秒
表 6 反応時間の多重比較

\begin{tabular}{|c|c|c|c|}
\hline タスク (1) & タาク (j) & $\begin{array}{l}\text { म } \\
1\end{array}$ & 有意碓 采 \\
\hline 追従 運転（往 路) & 追従運転（復路) & $4.22 \mathrm{E}-02$ & 0.898 \\
\hline 追従運転（往路） & 意通会話 & -0.1522 & 0.065 \\
\hline 追 従 運転（往 路) & 暗算課題 & -0.2928 & 0.000 \\
\hline 追従運転 (得路) & 童通会話 & -0.1943 & 0.011 \\
\hline 追従運転 (徣路) & 暗算諳題 & -0.335 & 0.000 \\
\hline 偪逼話 & 暗算課題 & -0.1407 & 0.105 \\
\hline
\end{tabular}

表 7 主観的メンタルワークロードの多重比較

\begin{tabular}{|c|c|c|c|}
\hline タスク(1) & タスク(J) & $\begin{array}{c}\text { 平均値の } \\
\text { 差 }(1-J)\end{array}$ & 有意確串 \\
\hline 追従運転（往路 & 電話操作 (往路) & $-9.94 \mathrm{E}-01$ & 0.000 \\
\hline 追従運転 (往路) & 追従運転 (復路) & 0.1667 & 0.980 \\
\hline 追従運転(往路) & 董話操作 (復路) & -0.5935 & 0.115 \\
\hline 追従運転(往路) & 普通会話 & -0.9129 & 0.001 \\
\hline 軍転(往路) & 暗算諳題 & -2.3645 & 0.000 \\
\hline 作 (往路) & 追従運転 (復路) & 1.1613 & 0.000 \\
\hline & 㬏話操作 (復路) & $4.00 \mathrm{E}-01$ & 0.527 \\
\hline 哓作 (往路) & 音通会話 & $8.07 \mathrm{E}-02$ & 0.999 \\
\hline 歷話操作 (往路) & 暗算課題 & -1.371 & 0.000 \\
\hline 追従運転（復路) & 電話操作 (復路) & -0.7613 & 0.015 \\
\hline 追従運転（復路) & 普通会話 & -1.0806 & 0.000 \\
\hline 追徥運転(復路) & 暗算課題 & -25323 & 0.000 \\
\hline 蹜話操作 (復路) & 尊通会話 & -0.3194 & 0.750 \\
\hline 量毠話操作 (復路) & 暗算課題 & $-1.77 E+00$ & 0.000 \\
\hline 普通会話 & 暗算 課題 & -1.4516 & 0.000 \\
\hline
\end{tabular}

(1.21 倍)の遅延及び主観的メンタルワークロードにおいて も 0.82 点 (1.18 倍) 増加し、両測度の比率が 1.02 となって いた。

著者らは、若年者及び高齢者といら2つのグループを実 験に用いることにより、各グループのメンタルワークロード 特性が得られると考えた。しかし、両者の反応時間及び主 観的メンタルワークロードは以上のような結果を示し、若年 者及び高齢者の 2 つのグループ間で有意な差を示すこと は無かった。これらのような結果は、高速道路における実 車実験であったため、高齢者の場合、実験に参加可能な 現役ドライバーのみを採用したからだと考えられる。

\section{5. まとめ}

本実験の結果は、著者らが平成 9 年度に行った研究結 果 ${ }^{2)}$ と同様に電話タスク時における反応時間及び主観的 メンタルワークロードが追従運転時に比べて増加している ことを示した。

会話内容に関しては、普通会話に比べて暗算課題では 記憶及び考察が大きく要求された。暗算課題時の反応時 間は、普通会話に比べて若年者及び高齢者とも長くなつ ていた。また、主観的メンタルワークロードでも暗算課題に 対する両者の評価が他のタスクに比べて有意に増加して いた。

反応時間の遅延に関しては、著者らがドライビングシミ ユレータを用いて行った実験 ${ }^{1)}$ の二次課題(ラジオ操作、 缶ジュース、ウインカー)の反応時間が約 0.9 秒であったこ とから、両者の反応時間を求める時の定義に違いはある が、今回のような普通会話及び暗算課題という 2 つの条件 においても運転への影響は、他の二次課題と同程度のレ 
ベルにあることが明らかとなった。しかし、このような結果は 限られた条件下において得られたものであり、より複雑な 道路環境及び場面を考えた場合、ドライバーのメンタルワ ークロードは更に増加することが考えられる。

よって、携帯電話使用に起因した交通問題はデバイス の操作性に限らず、ドライバーの情報処理能力からも影響 を受けていることから、デバイスの高性能化のみに限らず、 それを利用する技能とルールをドライバーは身につける必 要があると言えよう。

\section{参考文献}

1） Tokunaga R.A.、小澤正志、萩原亨、高木秀貴、下 條晃裕: 自動車運転中の携帯電話使用・操作に関連 する問題の研究、自動車技術会論文集、Vol.30No.1、 JSAE-9930432、pp.127-131、1999 年 1 月。

2）Tokunaga R.A.、野並克弘、萩原亨、加賀屋誠一、下 條晃裕: 追従運転時の携帯電話使用による運転者の メンタルワークロードについて、土木計画学研究·論 文集 No.16、pp.895-901、1999 年 9 月。
3）自動車安全運転センター:携帯電話の使用が運転挙 動に及ぼす影響に関する調査研究、平成 9 年度調查 研究報告書、平成 10 年 3 月。

4）安部久晃: 走行中の携帯電話等の使用等禁止につ いて、月刊交通、pp.17-25、1999 年 7 月号。

5）長澤有恒:メンタルワークロード(MWL)に関する雑感、 人間工学、Vol.29 No.6、pp.336-338、1993 年 12 月。

6) Hart Sandra et al.: Development of NASA-TLX: Results and Theoretical Research, Human Mental Workload, pp. 139-183, North- Holland, 1988.

7）三宅晋司、神代雅晴:メンタルワークロードの主観的 評価法 (NASA-TLXとSWAT の紹介及び簡便法の提 案)、人間工学、Vol.29No.6、1993 年 12 月。

8）芳賀繁:NASA タスクロードインデックス日本語版の作 成と試行、鉄道総研報告、特集: 人間科学、Vol.8 No.1、pp.15-20、1994 年 1 月。

9) Alm Hakan \& Nilsson Lena: Effects of Mobile Telephone Use on Elderly Drivers' Behavior including comparisons to young drivers' behavior, V. T. Isartryck 176, Sweden 1991.

携帯電話を利用した会話が自動車運転者に及ぼす影響について

徳永 ロベルト アブラル 萩原 亨 加賀屋 誠一 小野寺 雄輝

本研究では、自動車運転中の携帯電話を通した会話内容の違いがドライバーに与える影響を反応時間の遅延及 び主観的メンタルワークロードから測定した。被験者の反応時間の測定は、実験車両に設置された計測機器及び デジタルビデオカメラによって行われた。被験者の主観的メンタルワークロードの推定は、NASA Task Load Index のアンケート方式で行った。実験は、道央自動車道において行った。実験には、若年者 19 名及び高齢者 12 名計 31 名の被験者が参加した。被験者は、先行車両と一定の車間距離を維持しながら走行した。被験者には、（1）追 従運転、（2）追従運転中に電話の受信操作をする、（3）追従運転中に携帯電話を通して実験者と普通会話を行う 及び (4) 追従運転中に携帯電話を通して暗算課題を行うという4つのタスクが与えられた。実験の結果は、平成 9 年度の実験結果と同様に運転タスクに比べて電話タスクにおける若年者・高齢者の反応時間及び主観的メンタ ルワークロードが増加することを示した。会話内容の変化に関しては、暗算課題時の反応時間は普通会話に比べ て若年者及び高齢者とも長くなっていた。また、主観的メンタルワークロードでも暗算課題に対する両者の評価が他の夕ス クに比べて有意に増加していた。

Effects of Talking through Cellular Telephone while Driving

By R. A. Tokunaga, T. Hagiwara, S. Kagaya and Y. Onodera

In this study, the effects of conversation through cellular telephone while driving on driver reaction time and subjective mental w orkload (SMWL) w ere i nvestigated. Two vehicles e quipped with measurement de vices were u sed $\mathrm{t}$ o $\mathrm{m}$ easure reaction time. The drivers' SMWL was measured by the NASA Task Load Index procedure. The experiment was conducted on an expressway in Japan. Thirty-one subjects participated in the experiment. Nineteen of the subjects were young drivers and twelve subjects were elderly drivers. Each subject was asked to follow a leading vehicle and to keep a constant distance while following. The subjects performed four tasks: (1) following a leading vehicle, (2) operating a cellular telephone while following the leading vehicle, (3) perform a simple conversation task, and (4) perform a complex conversation task on a cellular telephone with the experimenter while following the leading vehicle. The results of these experiments indicated that the performance of the telephone tasks increase the reaction time and SMWL of the drivers as was shown in a previous study. The results also indicated that complex conversation task produced an increase in reaction time as compared to the simple conversation $t$ ask independent of age group. Furthermore, the experiment indicated that SMWL also increased significantly in the complex conversation task as compared to the other tasks. 